\title{
Where are the undiscovered hydrothermal vents on oceanic spreading ridges?
}

Stace E. Beaulieu ${ }^{\mathrm{a} *}$, Edward T. Baker ${ }^{\mathrm{b}}$, and Christopher R. German ${ }^{\mathrm{a}}$

${ }^{a}$ Woods Hole Oceanographic Institution, 266 Woods Hole Rd., Woods Hole, MA 02543 USA (* stace@whoi.edu) (+1 508-289-3536)

${ }^{\mathrm{b}}$ Joint Institution for the Study of the Atmosphere and Ocean-PMEL, University of Washington, Seattle WA 98115 USA

30 January 2015

Revised for Deep-Sea Research II, special issue for Peter Rona 


\section{ABSTRACT}

In the nearly four decades since the discovery of deep-sea vents, one-third of the length of global oceanic spreading ridges has been surveyed for hydrothermal activity. Active submarine vent fields are now known along the boundaries of 46 out of 52 recognized tectonic plates. Hydrothermal survey efforts over the most recent decade were sparked by national and commercial interests in the mineral resource potential of seafloor hydrothermal deposits, as well as by academic research. Here we incorporate recent data for back-arc spreading centers and ultraslow- and slow-spreading mid-ocean ridges (MORs) to revise a linear equation relating the frequency of vent fields along oceanic spreading ridges to spreading rate. We apply this equation globally to predict a total number of vent fields on spreading ridges, which suggests that $\sim 900$ vent fields remain to be discovered. Almost half of these undiscovered vent fields (comparable to the total of all vent fields discovered during 35 years of research) are likely to occur at MORs with full spreading rates less than $60 \mathrm{~mm} / \mathrm{yr}$. We then apply the equation regionally to predict where these hydrothermal vents may be discovered with respect to plate boundaries and national jurisdiction, with the majority expected to occur outside of states' exclusive economic zones. We hope that these predictions will prove useful to the community in the future, in helping to shape continuing ridge-crest exploration.

\section{Keywords}

Hydrothermal springs, Hydrothermal activity, Mid-ocean ridges, Spreading centers, Plate boundaries 


\section{Introduction}

Since the first observations of deep seafloor hot springs, or hydrothermal vents, at the Galápagos Rift in 1977, submarine hydrothermal activity has been studied in all ocean basins, over a wide range in depth, and in diverse volcanic and tectonic settings. Exploration was initially directed at fast-spreading mid-ocean ridges (MORs), focused by the presumption at that time that the comparatively weak magmatic budget of slow-spreading ridges would translate to negligible venting. Peter Rona offered a prominent and passionate dissent to this view, starting even before the Galápagos discoveries. In 1974, Peter and co-authors published the first paper hypothesizing the existence of a hydrothermal site on a slow-spreading ridge: TAG, near $26^{\circ} \mathrm{S}$ on the Mid-Atlantic Ridge (Scott et al., 1974). Over the next decade, Peter doggedly collected evidence that TAG not only provided a record of past hydrothermal discharge, but was presently active. His persistence was spectacularly rewarded in 1985 by the discovery of black smokers and a massive sulfide mound at TAG (Rona et al., 1986), a site "the size of the Houston Astrodome" in Peter's colorful language. This discovery opened the community's eyes to a wider geologic, chemical, and biological diversity than imagined along the global ridge crest. Fittingly, one of Peter's last publications was the landmark AGU Geophysical Monograph 188, which summarized decades of work on the diversity of hydrothermal systems on slow-spreading ridges (Rona et al., 2010). Our paper on the worldwide distribution of hydrothermal vents, written in the spirit of Peter's enthusiasm for exploration, is dedicated to his memory.

Motivations for the first hydrothermal discoveries were primarily in the geosciences and geared towards understanding seafloor spreading and the role of hydrothermal circulation in cooling of the ocean crust and as a source for heat and chemical fluxes to the ocean. The discovery of unique life endemic to deep-sea vents created an entirely new field of marine 
biology, expressed more recently in the efforts of the Census of Marine Life, to better understand the biogeography and connectivity between hydrothermal oases (Baker et al., 2010; Moalic et al., 2012). These motivations continue, complemented by renewed commercial interest in the inventory and distribution of seafloor massive sulfide deposits (Hannington et al., 2011), and by advances in quantifying vent discharge on chemical and biogeochemical cycling in the ocean (Amend et al., 2011; German and Seyfried, 2014).

Systematic surveys for hydrothermal activity, with a goal of locating active vent fields at the seafloor, have been reviewed at roughly decadal intervals, with previous compilations for the 1980's and 1990's (Baker et al., 1995; Baker and German, 2004). Here, we not only compile systematic hydrothermal surveys of mid-ocean ridges (MORs) and back-arc spreading centers (BASCs) during the 2000's, but also assign surveyed lengths to specific plate boundaries and national jurisdictions. In conjunction with the most recent data on locations of active vent fields (Beaulieu et al., 2013), we include new hydrothermal surveys along ultraslow, slow, and BASC ridges to revise the equation for a linear relationship between vent field frequency and spreading rate. This linear relationship has been described as the magmatic budget hypothesis; i.e., variability in magma supply is the primary control on the large-scale hydrothermal distribution pattern along spreading ridges (Baker and German, 2004). Building on the assumptions of the magmatic budget hypothesis (Baker and German, 2004), we estimate the number of vent fields remaining to be discovered at spreading ridge axes. Further, and recognizing uncertainties in applying the global analysis to specific regions, we predict how many hydrothermal vents are likely to be discovered per MOR and BASC region and according to national jurisdiction within exclusive economic zones (EEZs). We provide these results in the context of national and 
commercial interests in seafloor hydrothermal deposits as potential mineral resources and also in the context of connectivity and biogeography of vent-endemic fauna.

\section{A global inventory of surveyed spreading ridges}

In this global compilation, we explicitly relate systematic hydrothermal surveys on MORs and BASCs to the submarine oceanic spreading ridge (OSR) "digitization steps" and a subset of continental rift boundary (CRB) steps in the PB2002 model of plate boundaries (Bird, 2003). We use 1968 digitization steps in our analysis, with a mean length of $36 \mathrm{~km}$ and length range from $1 \mathrm{~km}$ to $103 \mathrm{~km}$ (Supp. Data). For 46 of the 52 plates in the PB2002 model (Bird, 2003), active submarine vent fields are known from at least one boundary (Fig. 1, Supp. Table 1). A re-analysis of surveyed strike length using the PB2002 model (Bird, 2003) confirms that as of the previous review (Baker and German, 2004), 20\% of the global ridge crest had been at least sparsely surveyed for hydrothermal activity, including $22 \%$ of the $\sim 60,000 \mathrm{~km}$ of MORs but only $11 \%$ of $\sim 11,000 \mathrm{~km}$ of BASCs (Supp. Table 1; see Supp. Information for categorization of survey density).

In the past decade, an additional $12 \%$ of the global ridge crest was systematically surveyed at least sparsely for hydrothermal activity, bringing the total surveyed to one-third of the global strike length (Supp. Table 1). In this study, eight recently surveyed portions of the global ridge crest, plus one earlier survey, have been added (and another was extended) to prior syntheses to revise the equation for a linear relationship between vent field frequency and spreading rate. Six of these newly surveyed regions reflect national and commercial interests in assessing the potential for seafloor mineral deposits (Table 1A). Much of the recent effort was 
directed toward BASCs, which are now $35 \%$ surveyed as compared to $32 \%$ of MORs (Table 1 , Supp. Table 1). Systematic hydrothermal surveys in the past decade were facilitated by advancements in technology such as increased use of Miniature Autonomous Plume Recorders (MAPRs) now equipped with Oxidation-Reduction Potential sensors (ORPs) that enable the detection of hydrothermal plumes on operations such as rock cores, dredges, and sonar tows.

Systematic hydrothermal survey efforts at MORs over the past decade were mainly at slow (20-55 mm/yr) spreading regions (over half of new strike length surveyed), followed by intermediate $(55-80 \mathrm{~mm} / \mathrm{yr})$, fast $(80-140 \mathrm{~mm} / \mathrm{yr})$, and ultraslow $(<20 \mathrm{~mm} / \mathrm{yr})$ spreading regions (Fig. 2A, Supp. Data). Surveys at slow MORs also reflect recent interests in ultramafic-hosted vents and the association of hydrothermal activity with oceanic core complexes and detachment faults (Snow and Edmonds, 2007; Escartin et al., 2008; German et al., 2010; McCaig and Harris, 2012; Son et al., 2014).

For BASCs systematic survey efforts were about equal at slow and fast spreading regions, followed by intermediate, ultraslow, and superfast (> $140 \mathrm{~mm} / \mathrm{yr}$ ) (Fig. 2B, Supp. Data). The global proportion of surveyed ridge strike length within EEZs almost doubled in the past decade, mainly as a result of these increased survey efforts at BASCs, and is now virtually identical to the proportion surveyed outside of EEZs (33\% within EEZs vs. $32 \%$ outside EEZs; Supp. Table 2). Certain national jurisdictions stand out. For example, the BASC strike lengths within the Papua New Guinea and Tonga EEZs are now $95 \%$ and $71 \%$ surveyed for hydrothermal activity, respectively, as compared to $0 \%$ one decade ago (Supp. Fig. 1A, Supp. Table 2). 


\section{Predicting the number of undiscovered vent fields on spreading ridges}

To predict the number of active vent fields remaining to be discovered at spreading ridges, we used an empirical relationship between the spatial density, or frequency (per $100 \mathrm{~km}$ ), of vent fields and spreading rate. Previous studies indicated that the frequency of hydrothermal activity on MORs has a strong linear relationship to spreading rate, a proxy for the long-term magma budget, but that this relationship does not appear to hold on hotspot-affected ridge segments (Dyment et al., 2007; (Baker et al., 2008b). The most recent prior compilation of systematic hydrothermal surveys (Baker and German, 2004) presented a linear equation for this relationship, which was revised slightly (Baker et al., 2004), based on 12 non-hotspot surveyed portions of MORs totaling $\sim 9 \%$ of the global ridge strike length. Here, we double this relatively densely surveyed strike length, extending one and adding nine more non-hotspot portions of ridge crest, for a linear regression of vent field frequency to spreading rate:

$$
\mathrm{F}_{\mathrm{s}}=0.95+0.020 \mathrm{u}_{\mathrm{s}}
$$

$\left(R^{2}=0.47\right.$; "21-pt linear regression" in Fig. $\left.3 \mathrm{~A}\right)$, where $\mathrm{F}_{\mathrm{s}}$ is the number of active vent fields per $100 \mathrm{~km}$ strike length and $\mathrm{u}_{\mathrm{s}}$ is weighted average full spreading rate ( $\left.\mathrm{mm} / \mathrm{yr}\right)$. Scatter among the

21 data points is expected due to variability in survey effort and discrimination of vent field locations (Baker et al., 2004). We also estimated the linear fit to all data points listed in Table 1A, including hotspot-affected regions and the Eastern Lau Spreading Center (ELSC)/Valu Fa Ridge (VFR):

$$
\mathrm{F}_{\mathrm{s}}=0.85+0.023 \mathrm{u}_{\mathrm{s}}
$$

$\left(\mathrm{R}^{2}=0.27\right.$; "27-pt linear regression" in Fig. 3A). The Lau ELSC/VFR nearly parallels the Tonga arc, and there is abundant evidence for arc magma contributing to unusually high levels of 
hydrothermal activity, especially where the actual spreading rate is in the slow category (Baker et al., 2006; Martinez et al., 2006). Listings in Table 1B were not of sufficient survey density and/or represented ridge sections $<200 \mathrm{~km}$ in length, or did not have data available for vent field locations. Locations for active vent fields, inclusive of high- and low-temperature venting, were determined from the InterRidge Vents Database, Version 2.1, with updates as described in (Beaulieu et al., 2013). Generally, this database distinguishes "a vent field as a cluster or assemblage of vent sites in relatively close proximity (i.e., on the order of 0.1-1 km)" (Beaulieu et al., 2013). We excluded off-axis, active vent fields. Additional details on methods are provided in the Supplementary Information.

In previous publications for this linear relationship, to achieve a minimum ridge length of $>500 \mathrm{~km}$ for each data point and thus reduce scatter (Baker and German, 2004; Baker et al., 2004), data were binned into five spreading rate categories: ultraslow (0-20 mm/yr), slow (20-55 $\mathrm{mm} / \mathrm{yr}$ ), intermediate $(55-80 \mathrm{~mm} / \mathrm{yr})$, fast $(80-140 \mathrm{~mm} / \mathrm{yr})$, and superfast (>140 mm/yr). To update the previously published equation, we binned the 21 non-hotspot surveyed portions of spreading ridges into the same five spreading rate categories and report as Eq. 3 the binned fit:

$$
\mathrm{F}_{\mathrm{s}}=0.85+0.021 \mathrm{u}_{\mathrm{s}}
$$

$\left(\mathrm{R}^{2}=0.88\right.$, greater coefficient of determination than Eq. 1; Fig. 3B). The new Eq. 3 is more representative of global spreading ridges, with the inclusion of data for slower spreading rates noted as lacking in the previous compilation (Baker and German, 2004), and the correlation for the binned data points is significant $(\mathrm{r}=0.94$, $\mathrm{p}$-value 0.018; also see Supp. Information). The slope of Eq. 3 is slightly steeper than the previously published relationship (Baker et al., 2004). Similarly, the new global average $\mathrm{F}_{\mathrm{s}}, 1.8$, is slightly greater than previous estimates (e.g., 1.7 in 
Baker et al., 2008a). Our new estimates for $\mathrm{F}_{\mathrm{s}}$ translate to average spacing between active vent fields ranging from $\sim 90 \mathrm{~km}$ on ultraslow $\left(\mathrm{F}_{\mathrm{s}} 1.1, \mathrm{u}_{\mathrm{s}} 10 \mathrm{~mm} / \mathrm{yr}\right)$ to $\sim 25 \mathrm{~km}$ for superfast $\left(\mathrm{F}_{\mathrm{s}} 4.1, \mathrm{u}_{\mathrm{s}}\right.$ $150 \mathrm{~mm} / \mathrm{yr}$ ). These are closer than estimated independently for seafloor massive sulfide (SMS) deposits (a proxy for high-temperature vent fields) using a very different method that does not consider spreading rate (Hannington et al., 2011), but this was to be expected since our approach also includes low temperature venting which does not give rise to massive sulfide deposits at the seafloor (see Supp. Information).

Of the nine new points added for the "21-pt" and binned fits, five of the MOR points and one of the BASC points are at ultraslow to slow spreading rates (Fig. 3). The consistency of the non-zero intercept for vent field frequency at zero spreading rate, further supports the possibility that at ultraslow and slow spreading rates additional heat sources such as serpentinization can produce more vent fields per volume of injected melt than predicted by the magmatic budget hypothesis alone. However, the confidence interval of the slope includes zero $\mathrm{F}_{\mathrm{s}}$ at $0 \mathrm{~mm} / \mathrm{yr}$, so the present regression giving $F_{s}=0.85$ at $0 \mathrm{~mm} / \mathrm{yr}$ (Eq. 3) may conversely be a sampling artifact such as limited sampling at spreading rates $>100 \mathrm{~mm} / \mathrm{yr}$ (Fig. 3). With the exception of the Lau ELSC/VFR, BASC points appear consistent with MOR points in the $\mathrm{F}_{\mathrm{s}} \mathrm{vs} . \mathrm{u}_{\mathrm{s}}$ scatterplot (Fig. 3A). SMS deposit frequencies on BASCs were also found to be similar to those on MORs with similar spreading rates (Hannington et al., 2011).

Using the new Eq. 3, we would now predict a total of 1305 active vent fields on spreading ridges (95\% confidence limits 713-1853), higher than but within the 95\% confidence interval of previous estimates based on a linear relationship of vent field frequency to spreading rate (Baker et al., 2004) (see Supp. Information). In Fig. 4, we resolve the total number of predicted vent fields per tectonic setting, 1100 vent fields on MORs ( $v s . ~ \sim 300$ presently known) 
and 200 on BASCs (vs. 100 presently known), and per spreading rate in $20 \mathrm{~mm} / \mathrm{yr}$ bins. We subtract the number of known active vent fields to resolve the number of undiscovered vent fields per spreading rate (Fig. 4), per region (Fig. 2, Supp. Table 1), and per national jurisdiction within EEZs (Supp. Fig. 1B, Supp. Table 2) (i.e., the predicted values are not based on unsurveyed strike lengths). The previous review reported that $21 \%$ of the predicted total vent fields on spreading ridges was known (Baker and German, 2004); now we know 33\% of the current prediction. Both percentages match that of total strike length systematically surveyed for hydrothermal activity at the time of publication.

\section{Where are the undiscovered hydrothermal vents on oceanic spreading ridges?}

In the following sections we assign the global prediction of active vent fields on spreading ridges to particular regions of MORs and BASCs. We note the scatter and the confidence interval for the linear fit in Fig. 3, which indicates that variability is to be expected when applying the global equation to a particular region. For example, the number of known active vent fields in some well-studied regions already exceeds the predicted total number based on the global equation (Supp. Table 1). Therefore, when interpreting the predicted number of undiscovered vents for any yet-to-be-surveyed region or national jurisdiction, it is important to remember the uncertainties associated with any application of the globally-derived Eq.3 at the more localized regional/basin scale.

4.1 Where are the undiscovered hydrothermal vents on mid-ocean ridges? 
We estimate that almost $3 / 4$ of the total number of vent fields predicted to exist worldwide at MORs remain to be discovered (780/1099; Supp. Table 1). Even accounting for the lower $\mathrm{F}_{\mathrm{s}}$ at slower spreading rates, about half of these (i.e., 400) undiscovered vents are expected to be found at ultraslow- and slow-spreading MORs (Fig. 4A). Regions with these slower average spreading rates that are likely to host the most undiscovered vents are the Southern Mid-Atlantic Ridge (MAR), Northern MAR, Carlsberg Ridge, and Southwest Indian Ridge (SWIR) (Fig. 2A, Supp. Table 1). As of 2010, approximately $5000 \mathrm{~km}$ of strike length to the south of $14^{\circ} \mathrm{S}$ on the MAR, equatorial latitudes between the Vema $\left(\sim 11^{\circ} \mathrm{N}\right)$ and Chain $\left(\sim 1^{\circ}\right.$ S) Fracture Zones, and most of the length north of the Azores $\left(\sim 40^{\circ} \mathrm{N}\right)$ to the Charlie-Gibbs Fracture Zone $\left(\sim 52^{\circ} \mathrm{N}\right)$ had not been systematically surveyed for hydrothermal activity. Long lengths also remain unexplored at the Carlsberg Ridge and SWIR (Fig. 1), despite first systematic survey efforts along parts of these ridge axes in the past decade (Table 1). Further systematic hydrothermal surveys have been conducted in these regions since 2010 (see Supp. Information); recent discoveries of vent fields have been reported for the N MAR and Carlsberg Ridge (Tao et al., 2013). More vent fields are also expected to be found on the Galápagos Spreading Center, categorized as slow-spreading when including its lesser-explored westernmost (Galápagos microplate) portion (Fig. 2A, Supp. Table 1); a vent field was recently discovered on this microplate (Tao et al., 2011a). At high latitudes in the northern hemisphere, undiscovered vents are predicted for the Reykjanes Ridge which is still unsurveyed for hydrothermal activity from the Charlie-Gibbs Fracture Zone to $\sim 58^{\circ} \mathrm{N}$ (although, since it is hotspot-influenced, it may have fewer vents than predicted; German et al., 1994). Much of the strike length along the ultraslow spreading ridges of the Norwegian-Greenland Sea and about half of the Gakkel Ridge also remain to be surveyed for hydrothermal activity (Fig. 1, 2A; Supp. Table 1). Additional 
studies at Arctic MOR vents are warranted to confirm the new biogeographic province suggested for Arctic vent fauna (Pedersen et al., 2010a; Boetius et al., 2014, in press). Other ultraslow- and slow-spreading MOR regions that are intriguing for exploration include the Red Sea, Ayu Trough, Sorol Trough, and American-Antarctic Ridge (see Supp. Information).

For the other $\sim 400 \mathrm{MOR}$ vent fields yet to be discovered at faster spreading regions, the overwhelming majority are likely to arise in the southern hemisphere on the intermediatespreading Southeast Indian Ridge (SEIR) and Pacific-Antarctic Ridge and the fast-spreading Southern East Pacific Rise (S EPR) (Fig. 2A). Most of the intermediate-spreading ridge length outside EEZs in the southern hemisphere remains unsurveyed for hydrothermal activity (Fig. 1). Although 2500-km of the SEIR has been moderately to densely surveyed for hydrothermal activity (Baker et al., 2014), this is just a fraction of the $\sim 12,500-\mathrm{km}$ from the Rodriguez Triple Junction eastward to $38^{\circ} \mathrm{S}$ on the Pacific-Antarctic Ridge where no active vent fields have yet been visually confirmed. Further exploration of the intermediate-spreading Chile Rise and Pacific-Antarctic Ridge for vent-endemic fauna has also been called for as a follow-up to the past decade's Census of Marine Life (German et al., 2011). Exploration is also warranted at faster spreading rates, in particular 120-140 mm/yr (Fig. 4), which includes the N EPR near the equator and the S EPR at the Nazca-Pacific plate boundary (Fig. 1; note: plate identifiers are provided in Supp. Information). Exploration at these fast spreading rates will be particularly valuable in confirming the slope and intercept of the $\mathrm{F}_{\mathrm{s}} \mathrm{vs} . \mathrm{u}_{\mathrm{s}}$ regression (Fig. 3), as ridges spreading at these rates are under-explored/under-sampled compared with the rest of the global MOR system. Our predictions currently suggest that vent fields should occur every $25-30 \mathrm{~km}\left(\mathrm{~F}_{\mathrm{s}}\right.$ 3.4-3.8) along strike at these spreading rates. 


\subsection{Where are the undiscovered hydrothermal vents on back-arc spreading centers?}

We estimate that less than $1 / 2$ of the predicted total number of vent fields at BASCs (i.e., 100) remain to be discovered (90/206; Supp. Table 1). Two-thirds of these undiscovered vents are likely to occur at ultraslow to slow-spreading BASCs (Fig. 4B), in particular at the North Fiji Basin and the Taupo Volcanic Zone/Havre Trough and Mariana Trough (Fig. 2B). Two plate boundaries, each almost $500 \mathrm{~km}$ in length, remain completely unsurveyed for hydrothermal activity in the North Fiji Basin: the ultraslow Hazel Holme extensional zone (New HebridesPacific boundary) and slow-spreading South Pandora and Tripartite Ridges (Pacific-Balmoral Reef boundary). The Havre Trough was the target of a very recent hydrothermal survey (Supp. Information). Hydrothermal surveys are planned in 2015 for the Mariana Trough at $13-18^{\circ} \mathrm{N}$ (W. Chadwick, personal communication). Several vents may be discovered along the relatively unsurveyed slow-spreading BASCs of the Okinawa Trough and Andaman Basin, although systematic hydrothermal surveys may be difficult in sedimented basins. The Andaman BASC is perhaps the most oceanographically isolated spreading center, and its investigation would be particularly interesting in terms of biogeography and potential endemic species.

We predict that the remaining BASC vent fields will be found at faster spreading regions (i.e., 100-140 mm/yr; Fig. 4B), including the relatively well-studied Lau and Manus Basins and in the fast-spreading portions of BASCs in North Fiji Basin. Although Fig. 2B implies that most (if not all) vents have been located in Lau Basin, this is because the number known is skewed by the unusually high vent frequency on the ELSC/VFR (Baker et al., 2006; Martinez et al., 2006). One-third of the strike length in Lau Basin remains to be systematically surveyed (Supp. Table 1), and the Tonga-Niuafo'ou and Pacific- Niuafo'ou plate boundaries have unsurveyed OSR steps with spreading rates in this range (Supp. Data). About a dozen more vents are predicted for the 
intermediate-spreading East Scotia Ridge (ESR) (Fig. 2B); only two vent-sites were located there to-date (Rogers et al., 2012), but only two of the nine segments of the ESR have yet been surveyed systematically (German et al., 2000). Other BASC regions intriguing for exploration are discussed in the Supplementary Information.

\subsection{Where are the undiscovered hydrothermal vents with respect to national jurisdiction?}

We predict that almost $3 / 4$ of the undiscovered vent fields on spreading ridges will be found outside of EEZs, in The Area (the seafloor beyond the limits of national jurisdiction) and on extended continental shelves (625/870; Supp. Table 2). Here, we allocate to national jurisdictions the 1/4 of the undiscovered vent fields that are predicted to be within EEZs (Supp. Fig. 1B; Supp. Table 2). For the undiscovered vent fields on spreading ridges in EEZs, Fiji clearly stands out, followed by New Zealand, Mexico, UK (specifically, the South Georgian EEZ), Ecuador (Galápagos), France (Amsterdam Island and Saint Paul Island), USA (Northern Mariana Islands and Guam), Yemen, and UK (British Indian Ocean Territory). Some of these predictions for total numbers of vent fields may be over-estimates because of the potential for hotspot influence to suppress high-temperature hydrothermal venting [e.g., France (Amsterdam Island and Saint Paul Island)]. Spreading ridges in both Fiji and New Zealand have been $\sim 1 / 3$ surveyed for hydrothermal activity, but almost all of the strike length in the USA's Northern Mariana Islands and Guam and all of the UK's British Indian Ocean Territory remain unsurveyed (Supp. Table 2). Spreading ridges in Japan's EEZ are unsurveyed in this analysis (the Izu-Bonin back-arc is not included in the PB2002 model) (Bird, 2003) (Supp. Fig. 1A), but there are many vent fields known as a result of targeted exploration (Supp. Table 2). While the 
total number of vents predicted for Tonga's EEZ has already been exceeded (Supp. Table 2), this is likely due to the remarkably high number of vent fields on the ELSC/VFR; $29 \%$ of Tonga's BASC strike length still remains to be surveyed for hydrothermal activity, and more vent fields surely remain to be discovered there.

At least $18 \%$ of active vent fields known globally are in areas granted or pending applications for mineral prospecting (Beaulieu et al., 2013). During the last decade, there were increased commercial and national interests in seafloor hydrothermal deposits' potential as mineral resources, heightened by the 2003-2008 boom in commodity prices (Hoagland et al., 2010). Many of the systematic hydrothermal surveys compiled for the most recent decade in Table 1 were conducted as searches for potential mineral resources [e.g., Manus Basin, SWIR 49-52 ${ }^{\circ}$ E, N MAR $11-21^{\circ} \mathrm{N}$, Central Indian Ridge (CIR) 8-17 ${ }^{\circ} \mathrm{S}$ ], and some were too recent to be included in the strike length compilation (see Supp. Information). The well-surveyed BASC regions in the scatterplot of $F_{s}$ vs. $u_{s}$ (Fig. 3) are all within EEZs of nations that have granted exploration tenements for polymetallic sulfides (Tonga, Papua New Guinea, and Solomon Islands). The first commercial mining lease for deep-sea SMS deposits was granted in 2011 by Papua New Guinea for Solwara 1 in Manus Basin; however, at the time of this writing, mining had not yet commenced. Interest within EEZs is not surprising due to easier access (shallower depth and proximity to land-based facilities) and due to fragmented governance outside of EEZs (Ardron et al., 2014; Mengerink et al., 2014). The International Seabed Authority adopted regulations in 2010 for prospecting and exploration for polymetallic sulfides in The Area, and as of 2014 six applications were approved from contractors representing six different national interests for exploration blocks on the CIR, SWIR, SEIR, and N MAR. Although the most recent estimates for copper and zinc indicate that the global resource of seafloor hydrothermal deposits 
is comparable to no more than one year's worth of production of these same metals from landbased mines (Hannington et al., 2011), interest in exploiting these mineral resources continues.

In parallel during the last decade, there was increased international interest in conservation and protection of deep-sea vents both within and outside EEZs (Van Dover, 2011; Ardron et al., 2014; Mengerink et al., 2014). However, only a few of the systematic hydrothermal surveys conducted during the past decade were associated with the Chemosynthetic Ecosystems (ChEss) project of the Census of Marine Life (e.g., S MAR 2.5-7º Table 1). This is not surprising, because many of the ChEss program cruise priorities were better achieved through follow-on cruises to observe, sample, and characterize, in detail, the biodiversity of vents that had been identified from earlier systematic hydrothermal surveys [e.g., (German et al., 2000) vs. (Rogers et al., 2012), (Edmonds et al., 2003) vs. (Boetius et al., 2014, in press)]. Individual nations are also making decisions with conservation in mind. For example, Fiji granted offshore exploration licenses to a private company in 2011, but excluded two application areas in North Fiji Basin with known active vent fields that host chemosynthesisbased ecosystems.

\section{Outlook for the next decade}

Assuming the linear relationship between vent field frequency and spreading rate, and recognizing the uncertainties in our calculations, we predict that almost half of the undiscovered vent fields on spreading ridges ( $\sim 400$, a number comparable to the total of all vent fields discovered during the first 35 years of hydrothermal research) are likely to occur at MORs with full spreading rates less than $60 \mathrm{~mm} / \mathrm{yr}$. This finding would have excited our colleague, Peter 
Rona, as it highlights the need for further research and exploration of slow-spreading ridges, as stressed in his recent edited monograph (Rona et al., 2010). The slower spreading ridges, which make up $~ 60 \%$ of the cumulative along-strike length of global oceanic spreading ridges, remain the least explored, and only there have tectonically controlled and/or ultramafic-hosted, hightemperature vent sites been found, with highly distinctive organic and inorganic vent-fluid chemistries (Rona et al., 2010). Interdisciplinary studies in a diversity of tectonic and volcanic settings, including vents in a variety of host rock types, will yield new insights into microbial and faunal adaptations and biogeochemical cycling in chemosynthetic ecosystems.

Although ultraslow and slow-spreading ridges are notoriously difficult to survey for hydrothermal activity (Baker and German, 2004), we expect increased use of AUVs equipped with chemical sensors to enhance these surveys in the future (German et al., 2008b; Devey et al., 2010). The use of hybrid ROV/AUVs would also enable sampling (German et al., 2011). Technology is now available to conduct AUV surveys for hydrothermal activity at the first-order segment scale ( 100 km) (Devey et al., 2010). Looking further into the future, very-long-range ( 1000 km) systematic surveys with AUVs will help us fill in the gaps in regions with logistical and weather challenges and/or under ice (Bellingham et al., 2010; Devey et al., 2010; German et al., 2011; German et al., 2012). Hydrothermal tracers (i.e., heat, optical, oxidation-reduction potential, methane, $\mathrm{Mn}, \mathrm{Fe},{ }^{3} \mathrm{He}$ ) have pronounced differences in sensitivity, range, life span, and data availability (German and Seyfried, 2014), and effective surveys will need both long-range tracers to detect distal plumes and short-range sensors to more precisely identify source locations.

Exploration for hydrothermal vents on ultraslow and slow-spreading ridges will continue to be driven by interests in mineral resources, given the relatively larger sizes of known deposits 
(Hannington et al., 2011), but also by academic interests to better understand regional and global impacts of fluxes of heat and materials from vents to the ocean, and the biodiversity and biogeography of these extreme environments. Investigations of high temperature vent systems on the ultra-slow spreading SWIR, Knipovich Ridge, and Mid-Cayman Rise have all resulted in the surprising discovery of unexpectedly large (hence, presumably, long-lived) hydrothermal fields hosted in neovolcanic settings (Pedersen et al., 2010b; Tao et al., 2012; Kinsey and German, 2013). The distinctive geochemistries, longevity of the hydrothermal systems, and greater distances between vent fields on ultraslow and slow-spreading ridges are important for population and ecosystem dynamics. Emerging interests in conservation and marine spatial planning (e.g., Van Dover et al., 2012) will benefit from an improved understanding of geophysical controls on vent distribution and persistence.

Many of the regions determined in our analysis as likely to host numerous undiscovered vents were also identified as high-priority targets by the InterRidge Working Group on LongRange Exploration (Devey et al., 2010). In terms of the greatest contiguous length of ridges to be explored for hydrothermal vents, there are only 8 confirmed vent fields along $21,000 \mathrm{~km}$ of spreading ridge encircling Antarctica, and a recent workshop advocated an international effort to survey Circum-Antarctic ridges in order to discover new tectonic contexts, new hydrothermal vents, and new species (Briais et al., 2011). In the next decade, we recommend more exploration that includes sampling to resolve continuing open questions on what controls the global biogeography and gene flow of vent fauna. In particular. we point to the Pacific-Antarctic Ridge within the South Pacific region which was also prioritized for future research by the ChEss project of the Census of Marine Life (German et al., 2011). In addition to the InterRidge Working Group's targets, which were mainly outside EEZs, we also recommend more 
exploration of spreading ridges adjacent to ocean margins within EEZs to explore for and identify species that are shared between multiple types of chemosynthetic ecosystems (e.g., cold seeps, large organic falls).

Finally, we note that the predictions made in this paper are constrained to vent fields in the neovolcanic zones of spreading ridges. There are relatively few known vent fields off-axis, although their discovery is accelerating. In 2000, Lost City, a low-temperature serpentinitehosted vent field, was discovered $\sim 15 \mathrm{~km}$ off-axis from the N MAR (Kelley et al., 2001). More recently, the high-temperature Nibelungen field was discovered hosted in pillow basalts $\sim 9 \mathrm{~km}$ distant from the S MAR axis at $8^{\circ} \mathrm{S}$ (Melchert et al., 2008). Our estimates also likely underestimate the total vent field population because of the historic difficulty in discovering purely low-temperature fields that do not discharge fluids readily detected by optical sensors. We also do not include submarine hydrothermal vent fields from volcanic arcs and intra-plate volcanoes, which account for $\sim 25 \%$ of today's known active submarine vent fields (Beaulieu $e t$ al., 2013). In this paper, we have highlighted the opportunities for discovery to be expected from continued exploration along spreading ridges. What seems equally certain is that the further exploration for vents in other tectonic settings should also be expected to continue to increase the known diversity and, consequently, our understanding of vent systems.

\section{Acknowledgments}

We thank A. Emerson, J. Llopiz, S. Mills, L. Mullineaux, and anonymous reviewers for improvements to the manuscript. S.B. was supported by NSF OCE08-38923, NSF GeoEd1202977, and WHOI Marquet Award, E.B. by the NOAA Vents (now Earth-Ocean Interactions) 
Program and the Joint Institute for the Study of the Atmosphere and Ocean (JISAO) under

NOAA Cooperative Agreement No. NA10OAR4320148, and C.G. by NSF OCE10-61863, NASA NNX09AB75G, and NOAA NA14OAR4320158. PMEL contribution 3948, JISAO contribution 2268.

\section{References}

Amend, J.P., McCollom, T.M., Hentscher, M., Bach, W., 2011. Catabolic and anabolic energy for chemolithoautotrophs in deep-sea hydrothermal systems hosted in different rock types. Geochimica et Cosmochimica Acta 75 (19), 5736-5748, doi: 10.1016/j.gca.2011.07.041.

Arculus, R., 2009. Voyage summary SS02/2009: Hydrothermal plume and structural geology mapping in the Tonga/Fiji region. Australian National University, 39 pp.

Arculus, R.J., McConachy, T.F., 2004. Voyage summary SS06/2004: Submarine volcanic and hydrothermal activity in the New Hebrides arc-backarc system. Australian National University, $12 \mathrm{pp}$.

Ardron, J.A., Rayfuse, R., Gjerde, K., Warner, R., 2014. The sustainable use and conservation of biodiversity in ABNJ: What can be achieved using existing international agreements? Marine Policy 49, 98-108, doi: 10.1016/j.marpol.2014.02.011.

Baker, E.T., 2009. Relationships between hydrothermal activity and axial magma chamber distribution, depth, and melt content. Geochemistry, Geophysics, Geosystems 10 (6), Q06009, doi: 10.1029/2009GC002424.

Baker, E.T., Edmonds, H.N., Michael, P.J., Bach, W., Dick, H.J.B., Snow, J.E., Walker, S.L., Banerjee, N.R., Langmuir, C.H., 2004. Hydrothermal venting in magma deserts: The ultraslow-spreading Gakkel and Southwest Indian Ridges. Geochemistry, Geophysics, Geosystems 5 (8), Q08002, doi: 10.1029/2004GC000712.

Baker, E.T., Embley, R.W., Walker, S.L., Resing, J.A., Lupton, J.E., Nakamura, K., de Ronde, C.E.J., Massoth, G.J., 2008a. Hydrothermal activity and volcano distribution along the Mariana arc. J. Geophys. Res. 113 (B8), B08S09, doi: 10.1029/2007JB005423.

Baker, E.T., German, C.R., 2004. On the global distribution of hydrothermal vent fields. In: German, C.R., Lin, J., Parson, L.M. (Eds.), Mid-Ocean Ridges: Hydrothermal Interactions Between the Lithosphere and Oceans. American Geophysical Union, Washington, D.C., pp. 245-266, doi: 10.1029/148GM10.

Baker, E.T., German, C.R., Elderfield, H., 1995. Hydrothermal plumes over spreading-center axes: Global distributions and geological inferences. In: Humphris, S., Zierenberg, R., Mullineaux, L.S., Thomson, R. (Eds.), Seafloor hydrothermal systems: Physical, chemical, 
biological, and geological interactions. American Geophysical Union, Washington, D.C., pp. 47-71, doi: 10.1029/GM091p0047.

Baker, E.T., Haymon, R.M., Resing, J.A., White, S.M., Walker, S.L., Macdonald, K.C., Nakamura, K., 2008b. High-resolution surveys along the hot spot-affected Galápagos Spreading Center: 1. Distribution of hydrothermal activity. Geochemistry, Geophysics, Geosystems 9 (9), Q09003, doi: 10.1029/2008GC002028.

Baker, E.T., Hemond, C., Briais, A., Maia, M., Scheirer, D.S., Walker, S.L., Wang, T., Chen, Y.J., 2014. Correlated patterns in hydrothermal plume distribution and apparent magmatic budget along $2500 \mathrm{~km}$ of the Southeast Indian Ridge. Geochem. Geophys. Geosyst., 15, doi: 10.1002/2014GC005344.

Baker, E.T., Martinez, F., Resing, J.A., Walker, S.L., Buck, N.J., Edwards, M.H., 2010. Hydrothermal cooling along the Eastern Lau Spreading Center: No evidence for discharge beyond the neovolcanic zone. Geochemistry, Geophysics, Geosystems 11 (8), Q08004, doi: 10.1029/2010GC003106.

Baker, E.T., Massoth, G.J., Nakamura, K., Embley, R.W., de Ronde, C.E.J., Arculus, R.J., 2005. Hydrothermal activity on near-arc sections of back-arc ridges: Results from the Mariana Trough and Lau Basin. Geochemistry Geophysics Geosystems 6 (9), Q09001, doi: 10.1029/2005GC000948.

Baker, E.T., Resing, J.A., Walker, S.L., Martinez, F., Taylor, B., Nakamura, K., 2006. Abundant hydrothermal venting along melt-rich and melt-free ridge segments in the Lau back-arc basin. Geophysical Research Letters 33 (7), L07308, doi: 10.1029/2005GL025283.

Baker, M.C., Ramirez-Llodra, E.Z., Tyler, P.A., German, C.R., Boetius, A., Cordes, E.E., Dubilier, N., Fisher, C.R., Levin, L.A., Metaxas, A., Rowden, A.A., Santos, R.S., Shank, T.M., Van Dover, C.L., Young, C.M., Warén, A., 2010. Biogeography, Ecology, and Vulnerability of Chemosynthetic Ecosystems in the Deep Sea. In: McIntyre, A.D. (Ed.), Life in the World's Oceans. Wiley-Blackwell, Chicester, West Sussex, U.K., pp. 161-182, doi: 10.1002/9781444325508.ch9.

Beaulieu, S.E., Baker, E.T., German, C.R., Maffei, A., 2013. An authoritative global database for active submarine hydrothermal vent fields. Geochemistry, Geophysics, Geosystems 14 (11), 4892-4905, doi: 10.1002/2013GC004998.

Bellingham, J.G., Hobson, B., Godin, M.A., Kieft, B., Erikson, J., McEwen, R., Kecy, C., Zhang, Y., Hoover, T., Mellinger, E., 2010. A Small, Long-Range AUV with Flexible Speed and Payload. Ocean Sciences Meeting, 22-26 February 2010, Portland, Oregon USA, abstract \# MT15A-14.

Bird, P., 2003. An updated digital model of plate boundaries. Geochemistry, Geophysics, Geosystems 4 (3), 1027, doi: 10.1029/2001GC000252.

Boetius, A., Bach, W., Borowski, C., Diehl, A., German, C., Kaul, N., Köhler, J., Marcon, Y., Mertens, C., Molari, M., Schlindwein, V., Türke, A., Wegener, G., 2014, in press. Exploring the Habitability of Ice-covered Waterworlds: The Deep-Sea Hydrothermal System of the Aurora Mount at Gakkel Ridge, Arctic Ocean (8254' N, 6 $15 \mathrm{~W}, 4000 \mathrm{~m})$. American Geophysical Union, Fall Meeting. 
Briais, A., Park, S.-H., Chavagnac, V., Graham, D., Hanan, B., Hémond, C., Lin, J., Maia, M., Sauter, D., Tao, C., 2011. InterRidge International Workshop: Circum-Antarctic Ridges, 2830 September, 2011, Toulouse, France.

Chen, Y.J., Zhu, J., Lin, J., Guo, S., Baker, E.T., 2006. Hydrothermal plume anomalies along the East Pacific Rise near the equator. American Geophysical Union, Fall Meeting, Eos Trans. AGU, Fall Meet. Suppl. 87 (52), OS31D-1670.

Cherkashov, G., Poroshina, I., Stepanova, T., Ivanov, V., Bel'tenev, V., Lazareva, L., Rozhdestvenskaya, I., Samovarov, M., Shilov, V., Glasby, G.P., Fouquet, Y., Kuznetsov, V., 2010. Seafloor massive sulfides from the northern equatorial Mid-Atlantic Ridge: New discoveries and perspectives. Marine Georesources \& Geotechnology 28 (3), 222-239, doi: 10.1080/1064119X.2010.483308.

Connelly, D.P., German, C.R., Asada, M., Okino, K., Egorov, A., Naganuma, T., Pimenov, N., Cherkashev, G., Tamaki, K., 2007. Hydrothermal activity on the ultra-slow spreading southern Knipovich Ridge. Geochemistry, Geophysics, Geosystems 8 (8), Q08013, doi: 10.1029/2007GC001652.

Devey, C., German, C., Mello, S., Campos, L., Le Roux, A., Van Dover, C., Griffiths, G., Nakamura, K., Kumagai, H., Li, J., Maia, M., 2010. Long-Range Exploration of the Ridge Crest: An international workshop, 28-30 June 2010, National Oceanography Centre, Southampton, UK, workshop report available at http://www.interridge.org.

Devey, C.W., Lackschewitz, K.S., Baker, E., 2005. Hydrothermal and volcanic activity found on the Southern Mid-Atlantic Ridge. Eos, Transactions American Geophysical Union 86 (22), 209-212, doi: 10.1029/2005EO220001.

Dyment, J., Lin, J., Baker, E.T., 2007. Ridge-hotspot interactions: What mid-ocean ridges tell us about deep Earth processes. Oceanography 20 (1), 102-115, http://dx.doi.org/10.5670/oceanog.2007.84.

Edmonds, H.N., Michael, P.J., Baker, E.T., Connelly, D.P., Snow, J.E., Langmuir, C.H., Dick, H.J.B., Muhe, R., German, C.R., Graham, D.W., 2003. Discovery of abundant hydrothermal venting on the ultraslow-spreading Gakkel ridge in the Arctic Ocean. Nature 421 (6920), 252256, doi: 10.1038/nature01351.

Escartin, J., Smith, D.K., Cann, J., Schouten, H., Langmuir, C.H., Escrig, S., 2008. Central role of detachment faults in accretion of slow-spreading oceanic lithosphere. Nature 455 (7214), 790-794, doi: 10.1038/nature07333.

Gamo, T., Hasumoto, H., Okamura, K., Hatanaka, H., Mori, M., Chinen, M., Tanaka, J., Komatsu, D., Tamaki, K., Fujimoto, H., Tsunogai, U., Kouzuma, F., Hirota, A., 2001. Geochemical evidence for submarine hydrothermal activity in the Gulf of Aden, northwestern Indian Ocean. American Geophysical Union, Fall Meeting, abstract \#OS41A-0449, San Francisco, CA.

Gamo, T., Tsunogai, U., Ichibayashi, S., Chiba, H., Obata, H., Oomori, T., Noguchi, T., Baker, E.T., Doi, T., Maruo, M., Sano, Y., 2010. Microbial carbon isotope fractionation to produce extraordinarily heavy methane in aging hydrothermal plumes over the southwestern Okinawa Trough. Geochemical Journal 44, 477-487. 
German, C.R., Baker, E.T., Connelly, D.P., Lupton, J.E., Resing, J., Prien, R.D., Walker, S.L., Edmonds, H.N., Langmuir, C.H., 2006. Hydrothermal exploration of the Fonualei Rift and Spreading Center and the Northeast Lau Spreading Center. Geochemistry, Geophysics, Geosystems 7 (11), Q11022, doi: 10.1029/2006GC001324.

German, C.R., Bennett, S.A., Connelly, D.P., Evans, A.J., Murton, B.J., Parson, L.M., Prien, R.D., Ramirez-Llodra, E., Jakuba, M., Shank, T.M., Yoerger, D.R., Baker, E.T., Walker, S.L., Nakamura, K., 2008a. Hydrothermal activity on the southern Mid-Atlantic Ridge: Tectonically- and volcanically-controlled venting at $4-5^{\circ} \mathrm{S}$. Earth and Planetary Science Letters 273 (3-4), 332-344, http://dx.doi.org/10.1016/j.eps1.2008.06.048.

German, C.R., Bowen, A., Coleman, M.L., Honig, D.L., Huber, J.A., Jakuba, M.V., Kinsey, J.C., Kurz, M.D., Leroy, S., McDermott, J.M., de Lépinay, B.M., Nakamura, K., Seewald, J.S., Smith, J.L., Sylva, S.P., Van Dover, C.L., Whitcomb, L.L., Yoerger, D.R., 2010. Diverse styles of submarine venting on the ultraslow spreading Mid-Cayman Rise. Proceedings of the National Academy of Sciences 107 (32), 14020-14025, doi: 10.1073/pnas.1009205107.

German, C.R., Briem, J, Chin, C., Danielsen, M., Holland, S,, James, R., Jónsdottir, A., Ludford, E., Moser, C., Ólafsson, J., Palmer, M.R., Rudnicki, M.D., 1994. Hydrothermal activity on the Reykjanes Ridge: the Steinahóll vent-field at 6306'N. Earth Planet. Sci. Lett. 121, 647654.

German, C.R., Connelly, D.P., Evans, A.J., Murton, B.J., Curewitz, D., Okino, K., Statham, P.J., Parson, L.M., 2001. Hydrothermal activity along the Central Indian Ridge: Ridges, hotspots and philately. American Geophysical Union, Fall Meeting, San Francisco, CA.

German, C.R., Jakuba, M.V., Kinsey, J.C., Partan, J., Suman, S., Belani, A., Yoerger, D.R., 2012. A long term vision for long-range ship-free deep ocean operations: persistent presence through coordination of Autonomous Surface Vehicles and Autonomous Underwater Vehicles. IEEE-AUV Conference, 24-27 September 2012, Southampton, England.

German, C.R., Livermore, R.A., Baker, E.T., Bruguier, N.I., Connelly, D.P., Cunningham, A.P., Morris, P., Rouse, I.P., Statham, P.J., Tyler, P.A., 2000. Hydrothermal plumes above the East Scotia Ridge: an isolated high-latitude back-arc spreading centre. Earth and Planetary Science Letters 184 (1), 241-250, doi: 10.1016/S0012-821X(00)00319-8.

German, C.R., Parson, L.M., Murton, B.J., Bennett, S.A., Connelly, D.P., Evans, A.J., Prien, R.D., Ramirez-Llodra, E.Z., Shank, T.M., Yoerger, D.R., Jakuba, M., Bradley, A.M., Baker, E.T., Nakamura, K., 2005. Hydrothermal activity on the southern Mid-Atlantic Ridge: Tectonically- and volcanically-hosted high temperature venting at $2-7^{\circ} \mathrm{S}$. Eos Trans. AGU, 86(52), Fall Meet. Suppl., Abstract OS21C-04.

German, C.R., Ramirez-Llodra, E., Baker, M.C., Tyler, P.A., et al., 2011. Deep-Water Chemosynthetic Ecosystem Research during the Census of Marine Life Decade and Beyond: A Proposed Deep-Ocean Road Map. PLoS ONE 6 (8), e23259, doi: 10.1371/journal.pone.0023259.

German, C.R., Seyfried Jr, W.E., 2014. Hydrothermal Processes. In: Holland, H.D., Turekian, K.K. (Eds.), Treatise on Geochemistry. Elsevier, Oxford, pp. 191-233, doi: 10.1016/B978-008-095975-7.00607-0. 
German, C.R., Yoerger, D.R., Jakuba, M., Shank, T.M., Langmuir, C.H., Nakamura, K.-i., 2008b. Hydrothermal exploration with the Autonomous Benthic Explorer. Deep Sea Research I 55 (2), 203-219, doi: 10.1016/j.dsr.2007.11.004.

Hannington, M., Jamieson, J., Monecke, T., Petersen, S., Beaulieu, S., 2011. The abundance of seafloor massive sulfide deposits. Geology 39 (12), 1155-1158, doi: 10.1130/G32468.1.

Hoagland, P., Beaulieu, S., Tivey, M.A., Eggert, R.G., German, C., Glowka, L., Lin, J., 2010. Deep-sea mining of seafloor massive sulfides. Marine Policy 34 (3), 728-732, doi: 10.1016/j.marpol.2009.12.001.

Husson, L., Conrad, C.P., 2012. On the location of hotspots in the framework of mantle convection. Geophysical Research Letters 39 (17), L17304, doi: 10.1029/2012GL052866.

Kawagucci, S., Okamura, K., Kiyota, K., Tsunogai, U., Sano, Y., Tamaki, K., Gamo, T., 2008. Methane, manganese, and helium-3 in newly discovered hydrothermal plumes over the Central Indian Ridge, $18^{\circ}-20^{\circ} \mathrm{S}$. Geochemistry, Geophysics, Geosystems 9 (10), Q10002, doi: 10.1029/2008GC002082.

Kelley, D.S., Karson, J.A., Blackman, D.K., Frueh-Green, G.L., Butterfield, D.A., Lilley, M.D., Olson, E.J., Schrenk, M.O., Roe, K.K., Lebon, G.T., 2001. An off-axis hydrothermal vent field near the Mid-Atlantic Ridge at 30 N. Nature 412 (6843), 145-149, doi: $10.1038 / 35084000$.

Kim, J., Son, S.-K., Son, J.-W., Kim, K.-H., Shim, W.J., Kim, Hwan, C., Lee, K.-Y., 2009. Venting sites along the Fonualei and Northeast Lau Spreading Centers and evidence of hydrothermal activity at an off-axis caldera in the northeastern Lau Basin. Geochemical Journal 43 (1), 1-13.

Kinsey, J.C., German, C.R., 2013. Sustained volcanically-hosted venting at ultraslow ridges: Piccard Hydrothermal Field, Mid-Cayman Rise. Earth and Planetary Science Letters 380, 162-168, doi: 10.1016/j.epsl.2013.08.001.

Laurila, T.E., Petersen, S., Devey, C.W., Baker, E.T., Augustin, N., Hannington, M.D., 2012. Tectonic and magmatic controls on hydrothermal activity in the Woodlark Basin. Geochemistry, Geophysics, Geosystems 13 (9), Q09006, doi: 10.1029/2012GC004247.

Lupton, J.E., Arculus, R.J., Resing, J., Massoth, G.J., Greene, R.R., Evans, L.J., Buck, N., 2012. Hydrothermal activity in the Northwest Lau Backarc Basin: Evidence from water column measurements. Geochemistry, Geophysics, Geosystems 13 (5), Q0AF04, doi: 10.1029/2011GC003891.

Lupton, J., de Ronde, C., Sprovieri, M., Baker, E.T., Bruno, P.P., Italiano, F., Walker, S., Faure, K., Leybourne, M., Britten, K., Greene, R., 2011. Active hydrothermal discharge on the submarine Aeolian Arc. Journal of Geophysical Research: Solid Earth 116 (B2), B02102, doi: 10.1029/2010JB007738.

Lupton, J., Lilley, M., Baker, E., Butterfield, D., Embley, R., Silvers, B., Resing, J., Olson, E., Evans, L., Lebon, G., Greene, R., 2002. Gas Chemistry of Hydrothermal Systems of the Explorer Ridge, NE Pacific Ocean. American Geophysical Union, Fall Meeting, abstract \#T11C-1268, San Francisco, CA. 
Martinez, F., Taylor, B., Baker, E.T., Resing, J.A., Walker, S.L., 2006. Opposing trends in crustal thickness and spreading rate along the back-arc Eastern Lau Spreading Center: Implications for controls on ridge morphology, faulting, and hydrothermal activity. Earth and Planetary Science Letters 245 (3-4), 655-672, doi: 10.1016/j.eps1.2006.03.049.

Massoth, G.J., Puzic, J., Crowhurst, P., White, M., Nakamura, K., Walker, S.L., Baker, E.T., 2008. Regional Venting in the Manus Basin, New Britain Back Arc. American Geophysical Union, Fall Meeting, abstract \#V41B-2074.

McCaig, A.M., Harris, M., 2012. Hydrothermal circulation and the dike-gabbro transition in the detachment mode of slow seafloor spreading. Geology 40, 367-370, doi: 10.1130/G32789.1

McInnes, B.I.A., Arculus, R., Massoth, G., Baker, E., Chadwick, J., De Ronde, C., McConachy, T., Posai, P., Qopoto, C., 2000. Project SHAARC: Investigation of Submarine, Hydrothermally Active ARC Volcanoes in the Tabar-Lihir-Tanga-Feni Island and Solomon Island Chains. CSIRO Division of Exploration and Mining, 20 pp.

Melchert, B., Devey, C.W., German, C.R., Lackschewitz, K.S., Seifert, R., Walter, M., Mertens, C., Yoerger, D.R., Baker, E.T., Paulick, H., Nakamura, K., 2008. First evidence for hightemperature off-axis venting of deep crustal/mantle heat: The Nibelungen hydrothermal field, southern Mid-Atlantic Ridge. Earth and Planetary Science Letters 275 (1-2), 61-69, doi: 10.1016/j.epsl.2008.08.010.

Mengerink, K.J., Van Dover, C.L., Ardron, J., Baker, M., Escobar-Briones, E., Gjerde, K., Koslow, J.A., Ramirez-Llodra, E., Lara-Lopez, A., Squires, D., Sutton, T., Sweetman, A.K., Levin, L.A., 2014. A Call for Deep-Ocean Stewardship. Science 344 (6185), 696-698, doi: $10.1126 /$ science. 1251458 .

Merle, S., Embley, R., de Ronde, C., Davy, B., 2007. New Zealand American Submarine Ring of Fire 2007, R/V Sonne ROVARK cruise report, accessed online 22 July 2014 from http://oceanexplorer.noaa.gov/explorations/07fire/logs/aug16/media/nzasrof07_cruisereport_f inal.pdf.

Moalic, Y., Desbruyères, D., Duarte, C.M., Rozenfeld, A.F., Bachraty, C., Arnaud-Haond, S., 2012. Biogeography Revisited with Network Theory: Retracing the History of Hydrothermal Vent Communities. Systematic Biology 61, 127-137, doi: 10.1093/sysbio/syr088.

Murton, B.J., Baker, E.T., Sands, C.M., German, C.R., 2006. Detection of an unusually large hydrothermal event plume above the slow-spreading Carlsberg Ridge: NW Indian Ocean. Geophysical Research Letters 33 (10), L10608, doi: 10.1029/2006GL026048.

Pedersen, R.B., Rapp, H.T., Thorseth, I.H., Lilley, M.D., Barriga, F.J.A.S., Baumberger, T., Flesland, K., Fonseca, R., Frueh-Green, G.L., Jorgensen, S.L., 2010a. Discovery of a black smoker vent field and vent fauna at the Arctic Mid-Ocean Ridge. Nat Commun 1, 126, doi: 10.1038/ncomms 1124 .

Pedersen, R.B., Thorseth, I.H., Nygård, T.E., Lilley, M.D., Kelley, D.S., 2010b. Hydrothermal Activity at the Arctic Mid-Ocean Ridges. In: Rona, P.A., Devey, C.W., Dyment, J., Murton, B.J. (Eds.), Diversity Of Hydrothermal Systems On Slow Spreading Ocean Ridges. American Geophysical Union, Washington, D.C., pp. 67-89, doi: 10.1029/2008GM000783.

Ray, D., Kamesh Raju, K.A., Baker, E.T., Srinivas Rao, A., Mudholkar Abhay, V., Lupton, J.E., Surya Prakash, L., Gawas Rekha, B., Vijaya Kumar, T., 2012. Hydrothermal plumes over the 
Carlsberg Ridge, Indian Ocean. Geochemistry, Geophysics, Geosystems 13 (1), Q01009, doi: $10.1029 / 2011 \mathrm{GC} 003888$.

Rogers, A.D., Tyler, P.A., Connelly, D.P., Copley, J.T., James, R., Larter, R.D., Linse, K., Mills, R.A., Garabato, A.N., Pancost, R.D., Pearce, D.A., Polunin, N.V.C., German, C.R., Shank, T., Boersch-Supan, P.H., Alker, B.J., Aquilina, A., Bennett, S.A., Clarke, A., Dinley, R.J.J., Graham, A.G.C., Green, D.R.H., Hawkes, J.A., Hepburn, L., Hilario, A., Huvenne, V.A.I., Marsh, L., Ramirez-Llodra, E., Reid, W.D.K., Roterman, C.N., Sweeting, C.J., Thatje, S., Zwirglmaier, K., 2012. The Discovery of New Deep-Sea Hydrothermal Vent Communities in the Southern Ocean and Implications for Biogeography. PLoS Biol 10 (1), e1001234, doi: 10.1371/journal.pbio.1001234.

Rona, P.A., Devey, C.W., Dyment, J., Murton, B.J. (Eds.), 2010. Diversity of Hydrothermal Systems on Slow Spreading Ocean Ridges. American Geophysical Union, Monograph 188, Washington, D. C., doi: 10.1029/2008GM000783.

Rona, P.A., Klinkhammer, G., Nelsen, J.A., Trefry, J.H., Elderfield, H., 1986. Black smokers, massive sulfides and vent biota at the Mid-Atlantic Ridge. Nature 321, 33-37.

Scott, R.B., Rona, P.A., McGregor, B.A., Scott, M.R., 1974. The TAG hydrothermal field. Nature 251 (5473), 301-302, doi: 10.1038/251301a0.

Searle, R., Murton, B.J., and the J.C. Shipboard Scientific Party, 2008. Structure and development of the axial volcanic ridge: Cruise JC24 to the Mid-Atlantic Ridge, $45^{\circ} \mathrm{N}$. InterRidge News, 17, pp. 11-15.

Snow, J.E., Edmonds, H.N., 2007. Ultraslow-Spreading Ridges: Rapid Paradigm Changes. Oceanography 20 (1), 90-101.

Son, J., Pak, S.-J., Kim, J., Baker, E.T., You, O.-R., Son, S.-K., Moon, J.-W., 2014. Tectonic and magmatic control of hydrothermal activity along the slow-spreading Central Indian Ridge, $8^{\circ} \mathrm{S}-17^{\circ} \mathrm{S}$. Geochemistry, Geophysics, Geosystems 15 (5), 2011-2020, doi: 10.1002/2013GC005206.

Stoffers, P., Worthington, T., Hekinian, R., Petersen, S., Hannington, M., Türkay, M., Party, S.S.S., 2002. Silicic volcanism and hydrothermal activity documented at Pacific-Antarctic Ridge. Eos, Transactions American Geophysical Union 83 (28), 301-304, doi: 10.1029/2002EO000215.

Stoffers, P., Wright, I.C., de Ronde, C., Hannington, M., Villinger, H., Herzig, P., 1999. Littlestudied arc-backarc system in the spotlight. Eos, Transactions American Geophysical Union 80 (32), 353-359, doi: 10.1029/EO080i032p00353-01.

Tao, C., Li, H., Wu, G., Su, X., Zhang, G., 2011a. First hydrothermal active vent discovered on the Galapagos Microplate. American Geophysical Union, Fall Meeting, abstract \#OS11B1488.

Tao, C., Li, H., Yang, Y., Ni, J., Cui, R., Chen, Y., Li, J., He, Y., Huang, W., Lei, J., Wang, Y., 2011b. Two hydrothermal fields found on the Southern Mid-Atlantic Ridge. Science China Earth Sciences 54 (9), 1302-1303, doi: 10.1007/s11430-011-4260-8. 
Tao, C., Lin, J., Guo, S., Chen, Y.J., Wu, G., Han, X., German, C.R., Yoerger, D.R., Zhou, N., Li, H., Su, X., Zhu, J., 2012. First active hydrothermal vents on an ultraslow-spreading center: Southwest Indian Ridge. Geology 40 (1), 47-50, doi: 10.1130/G32389.1.

Tao, C., Lin, J., Wu, G., German, C.R., Yoerger, D.R., Chen, Y.J., Guo, S., Zeng, Z., Han, X., Zhou, N., Li, J., Xia, S., Wang, H., Ding, T., Gao, S., Qian, X., Cui, R., Zhou, J., Ye, D., Zhang8, Y., Zhang, D., Li, L., Zhang, X., Li, Y., Wu, X., Li, S., He, Y., Huang, W., Wang, Y., Wang, T., Li, X., Wang, K., Gai, Y., Baker, E.T., Nakamura, K., 2008. First active hydrothermal vent fields discovered at the equatorial southern East Pacific Rise. American Geophysical Union, Fall Meeting, abstract \#V41B-2081, San Francisco, CA.

Tao, C., Wu, G., Deng, X., Qiu, Z., Han, C., Long, Y., 2013. New discovery of seafloor hydrothermal activity on the Indian Ocean Carlsberg Ridge and Southern North Atlantic Ridge - progress during the 26th Chinese COMRA cruise. Acta Oceanologica Sinica 32 (8), 85-88, doi: 10.1007/s13131-013-0345-x.

Van Dover, C.L., 2011. Tighten regulations on deep-sea mining. Nature 470 (7332), 31-33, doi: 10.1038/470031a.

Van Dover, C.L., Smith, C.R., Ardron, J., Dunn, D., Gjerde, K., Levin, L., Smith, S., Dinard Workshop, C., 2012. Designating networks of chemosynthetic ecosystem reserves in the deep sea. Marine Policy 36, 378-381, doi: 10.1016/j.marpol.2011.07.002.

VLIZ, 2009. Maritime Boundaries Geodatabase, World EEZ version 5, released 2009-10-01, available online at http://www.marineregions.org/downloads.php\#eez.

Zhu, J., Lin, J., Guo, S., Chen, Y., 2008. Hydrothermal plume anomalies along the Central Indian Ridge. Chinese Science Bulletin 53 (16), 2527-2535, doi: 10.1007/s11434-008-0208-6.

\section{Figure Legends}

Fig 1. Map depicting portions of the global ridge crest remaining to be systematically surveyed for hydrothermal activity. Global map with color indicating spreading rate categorized to ultraslow (<20 mm/yr), slow (20-55 mm/yr), intermediate $(55-80 \mathrm{~mm} / \mathrm{yr})$, fast $(80-140 \mathrm{~mm} / \mathrm{yr})$, or superfast (>140 mm/yr) for steps in the PB2002 model (Bird, 2003) that have not been surveyed for hydrothermal activity (surveyed steps are plotted black). Other plotted datasets include plate boundaries (Bird, 2003) (thin black line), EEZs (VLIZ, 2009) (thin gray line), confirmed and inferred active vent fields in all tectonic settings (black open: square $=$ discovered prior to year 2000, circle $=$ discovered during or after year 2000; note: this includes 48 more vent 
fields than in (Beaulieu et al., 2013), and hotspots (Husson and Conrad, 2012) (gray open star)). Labels: CR, Carlsberg Ridge; EPR, East Pacific Rise; GSC, Galápagos Spreading Center; MAR, Mid-Atlantic Ridge; Pac. Ant. R, Pacific Antarctic Ridge; SEIR, Southeast Indian Ridge; SWIR, Southwest Indian Ridge.

Fig 2. Strike length remaining to be surveyed and number of undiscovered vent fields per MOR and BASC region. Surveyed strike lengths (left y-axis) and predicted numbers of undiscovered vent fields (right y-axis) of (A) MOR and (B) BASC regions, with regions arranged by increasing weighted average full spreading rate (regions associated to plate boundaries in Supp. Table 1). Blue $=$ included in previous review paper $($ Baker and German, 2004), red $=$ added new in this paper, yellow $=$ not surveyed for hydrothermal activity. Surveyed strike lengths include densely, moderately, and sparsely surveyed (all types 1-3 in Supp. Data).

Fig. 3. Linear fit of vent field frequency to spreading rate. Scatterplot of vent field frequency (per $100 \mathrm{~km}$ strike length, $\mathrm{F}_{\mathrm{s}}$ ) to full spreading rate (weighted average $\mathrm{mm} / \mathrm{yr}, \mathrm{u}_{\mathrm{s}}$ ) for hydrothermal surveys of sufficient type and length (listed in Table 1A). A. Blue = revised values for 12 surveys plotted in (Baker et al., 2004), red $=9$ new surveys for the 21-pt linear regression (Eq. 1), gray $=5$ hotspot-influenced portions and Lau ELSC/VFR included in the 27-pt linear regression (Eq. 2). Solid lines are linear fits: black $=21$ surveys, gray $=$ all 27 surveys. Dashed curved lines are 95\% C.I.s, colored respectively. B. Colored diamonds are 21 non-hotspot surveys binned into 5 spreading rate categories, with linear fit (Eq. 3). Horizontal and vertical bars indicate range for data points shown in A. 
Fig 4. Number of undiscovered vent fields per spreading rate in $20 \mathrm{~mm} / \mathrm{yr}$ bins. Stacked bar histogram of known and predicted number of active vent fields as functions of spreading rate for (A) MORs and (B) BASCs in 20 mm/yr bins, distinguishing those discovered since year 2000.

Note: the recent discoveries include 48 more vent fields than in (Beaulieu et al., 2013). 


\section{Table caption}

Table 1. Systematic hydrothermal surveys along spreading ridge axes. All portions of spreading ridges surveyed systematically for hydrothermal activity (plotted black on Fig. 1), organized by region. Survey types: 1 , dense; 2 , moderate; 3 , sparse. Vent field frequency $\left(\mathrm{F}_{\mathrm{s}}\right)$ and weighted average full spreading rate $\left(\mathrm{u}_{\mathrm{s}}\right)$ are provided for the 27 surveyed portions used for the linear regressions in Fig. 3. Regions are associated to plate boundaries and modeled survey lengths are summed in Supp. Table 1. EPR, East Pacific Rise; MAR, Mid-Atlantic Ridge; SEIR, Southeast Indian Ridge; SWIR, Southwest Indian Ridge.

A. 27 surveyed portions used for linear regressions of vent field frequency to spreading rate.

\begin{tabular}{|c|c|c|c|c|c|c|c|c|}
\hline Region & $\begin{array}{l}\text { Surveyed } \\
\text { portion }\end{array}$ & $\begin{array}{l}\text { Survey } \\
\text { type }\end{array}$ & $\begin{array}{l}\text { Length } \\
(\mathrm{km}) \\
\text { modeled }\end{array}$ & $\begin{array}{l}\text { Length } \\
(\mathrm{km}) \\
\text { measured }\end{array}$ & $\begin{array}{l}\text { Full } \\
\text { sprd. } \\
\text { rate } \\
(\mathrm{mm} / \mathrm{yr})\end{array}$ & $\begin{array}{l}\text { Vent field } \\
\text { freq. (per } \\
\text { modeled) }\end{array}$ & $\begin{array}{l}\text { Vent field } \\
\text { freq. (per } \\
\text { measured) }\end{array}$ & References* \\
\hline \multicolumn{9}{|l|}{ Mid-ocean ridge } \\
\hline Carlsberg Ridge & $2-4.5^{\circ} \mathrm{N}$ & 1 & 469.0 & 440 & 30.73 & 0.43 & 0.45 & $\begin{array}{l}\text { (Ray et al., } \\
\text { 2012) }\end{array}$ \\
\hline $\begin{array}{l}\text { Central Indian } \\
\text { Ridge }\end{array}$ & $8-17^{\circ} \mathrm{S}$ & 2 & 749.8 & 738 & 36.21 & 1.33 & 1.36 & $\begin{array}{l}\text { (Son et al., } \\
\text { 2014) }\end{array}$ \\
\hline $\begin{array}{l}\text { Central Indian } \\
\text { Ridge }\end{array}$ & $\begin{array}{l}18.25-21^{\circ} \mathrm{S}, \\
\text { includes hotspot- } \\
\text { influenced }\end{array}$ & 1 & 396.5 & 300 & 42.31 & 0.76 & 1.00 & $\begin{array}{l}\text { (German } \text { et } \\
\text { al., 2001), } \\
\text { (Kawagucci et } \\
\text { al., 2008) }\end{array}$ \\
\hline Explorer Ridge & $49.5-50.3^{\circ} \mathrm{N}$ & 1 & 113.6 & & & & & $\begin{array}{l}\text { (Lupton et al., } \\
\text { 2002) }\end{array}$ \\
\hline Gakkel Ridge & $6^{\circ} \mathrm{W}-85^{\circ} \mathrm{E}$ & 1 & 985.3 & 965 & 11.82 & 0.91 & 0.93 & $*$ \\
\hline $\begin{array}{l}\text { Galapagos } \\
\text { Spreading Center }\end{array}$ & $\begin{array}{l}89.7-95^{\circ} \mathrm{W} \text {, } \\
\text { hotspot- } \\
\text { influenced }\end{array}$ & 1 & 606.0 & 560 & 53.22 & 1.32 & 1.43 & $\begin{array}{l}\text { (Baker et al., } \\
\text { 2008b) }\end{array}$ \\
\hline Gorda Ridge & $41-43^{\circ} \mathrm{N}$ & 2 & 237.8 & 240 & 55.61 & 2.10 & 2.08 & $*$ \\
\hline $\begin{array}{l}\text { Juan de Fuca } \\
\text { Ridge }+\end{array}$ & $44.5-48.3^{\circ} \mathrm{N}$ & 1 & 437.1 & 480 & 56.11 & 3.45 & 3.96 & $*$ \\
\hline N EPR & $15.5-18.5^{\circ} \mathrm{N}$ & 1 & 335.7 & 335 & 77.02 & 1.79 & 1.79 & $*$ \\
\hline N EPR & $8.7-13.2^{\circ} \mathrm{N}$ & 1 & 536.8 & 515 & 98.14 & 3.91 & 4.08 & $*$ \\
\hline N MAR & $35.7-38^{\circ} \mathrm{N}$ & 2 & 368.3 & 340 & 20.28 & 3.26 & 3.53 & $*$ \\
\hline N MAR & $27-30^{\circ} \mathrm{N}$ & 2 & 403.4 & 375 & 23.07 & 0.74 & 0.80 & $*$ \\
\hline
\end{tabular}




\begin{tabular}{|c|c|c|c|c|c|c|c|c|}
\hline N MAR & $11-21^{\circ} \mathrm{N}$ & $1,2 \dagger$ & $1133.7 \S$ & 935 & 25.51 & 1.32 & 1.60 & $\begin{array}{l}\text { (Cherkashov } \\
\text { et al., 2010) }\end{array}$ \\
\hline Reykjanes Ridge & $\begin{array}{l}57.75-63.5^{\circ} \mathrm{N} \text {, } \\
\text { hotspot- } \\
\text { influenced }\end{array}$ & 1 & 784.0 & 750 & 19.77 & 0.38 & 0.40 & $*$ \\
\hline S EPR & $13.5-18.6^{\circ} \mathrm{S}$ & 1 & 624.0 & 585 & 145.47 & 3.85 & 4.10 & $*$ \\
\hline S EPR & $27.5-32.3^{\circ} \mathrm{S}$ & 1 & 503.2 & 440 & 158.29 & 2.78 & 3.18 & $*$ \\
\hline S MAR & $2.5-6.8^{\circ} \mathrm{S}$ & 1,2 & $494.4 \S$ & 450 & 32.38 & 0.40 & 0.44 & $\begin{array}{l}\text { (German et } \\
\text { al., 2005), } \\
(\text { German } e t \\
\text { al., 2008a) }\end{array}$ \\
\hline S MAR & $\begin{array}{l}7-11^{\circ} \mathrm{S} \text {, hotspot- } \\
\text { influenced }\end{array}$ & 1 & $454.5 \S$ & 450 & 33.17 & 0.88 & 0.89 & $\begin{array}{l}\text { (Devey et al., } \\
\text { 2005) }\end{array}$ \\
\hline SEIR & $\begin{array}{l}33-36^{\circ} \mathrm{S} \text { and } \\
39.5-42.5^{\circ} \mathrm{S}(77- \\
\left.100^{\circ} \mathrm{E}\right)\end{array}$ & 2 & 2128.6 & 2060 & 68.12 & 1.74 & 1.80 & $\begin{array}{l}*,(\text { Baker et } \\
\text { al., 2014) }\end{array}$ \\
\hline SEIR & $\begin{array}{l}36-39.5^{\circ} \mathrm{S} \\
\text { hotspot- } \\
\text { influenced }\end{array}$ & 2 & 346.9 & 445 & 64.43 & 0.58 & 0.45 & $\begin{array}{l}*,(\text { Baker et } \\
\text { al., 2014) }\end{array}$ \\
\hline SWIR & $10-16^{\circ} \mathrm{E}$ & 2 & 228.6 & 416 & 13.50 & 2.62 & 1.44 & $*$ \\
\hline SWIR & $16-23^{\circ} \mathrm{E}$ & 2 & 512.8 & 484 & 13.73 & 0.39 & 0.41 & $\begin{array}{l}*, \text { (Baker et } \\
\text { al., 2004) }\end{array}$ \\
\hline SWIR & $49-52^{\circ} \mathrm{E}$ & 1 & 284.3 & 270 & 11.89 & 1.41 & 1.48 & $\begin{array}{l}\text { (Tao et al., } \\
\text { 2012) }\end{array}$ \\
\hline SWIR & $\begin{array}{l}58.5-60.5^{\circ} \mathrm{E} \text { and } \\
63.5-66^{\circ} \mathrm{E}\end{array}$ & 1 & 523.3 & 430 & 9.83 & 1.34 & 1.63 & $*$ \\
\hline
\end{tabular}

\begin{tabular}{|c|c|c|c|c|c|c|c|c|}
\hline $\begin{array}{l}\text { Back-arc } \\
\text { spreading center }\end{array}$ & & & & & & & & \\
\hline Lau Basin & Lau ELSC/VFR & 1 & 421.7 & 400 & 64.36 & 7.59 & 8.00 & $\begin{array}{l}\text { (Baker et al., } \\
\text { 2005), (Baker } \\
\text { et al., 2006), } \\
\text { (Arculus, } \\
\text { 2009), } \\
\text { (Baker, 2009), } \\
\text { (E. Baker et } \\
\text { al., 2010) }\end{array}$ \\
\hline Lau Basin & $\begin{array}{l}\text { Lau NELSC, } \\
\text { MTJ, and FRSC }\end{array}$ & $1,2 \dagger$ & 336.5 & 340 & 87.59 & 4.16 & 4.12 & $\begin{array}{l}\text { (German } \text { et } \\
\text { al., 2006), } \\
\text { (Kim et al., } \\
\text { 2009), E. } \\
\text { Baker, unpub. } \\
\text { data }\end{array}$ \\
\hline Manus Basin & $\begin{array}{l}\text { all except } \\
\text { westernmost of } \\
\text { western rift }\end{array}$ & 1 & 405.6 & 405 & 101.43 & 2.71 & 2.72 & $\begin{array}{l}\text { (Massoth et } \\
\text { al., 2008) }\end{array}$ \\
\hline Woodlark Basin \| & $151.5-155.75^{\circ} \mathrm{E}$ & 2 & 464.1 & 520 & 30.64 & 0.60 & 0.58 & $\begin{array}{l}\text { (Laurila et al., } \\
\text { 2012) }\end{array}$ \\
\hline Woodlark Basin \| & $156.1-156.4^{\circ} \mathrm{E}$ & 2 & 37.3 & & & & & $\begin{array}{l}\text { (McInnes et } \\
\text { al., 2000) }\end{array}$ \\
\hline
\end{tabular}


B. Other surveyed portions included in the global compilation

\begin{tabular}{|c|c|c|c|c|}
\hline Region & $\begin{array}{l}\text { Surveyed } \\
\text { portion }\end{array}$ & $\begin{array}{l}\text { Survey } \\
\text { type }\end{array}$ & $\begin{array}{l}\text { Length } \\
(\mathrm{km}) \\
\text { modeled }\end{array}$ & References* \\
\hline \multicolumn{5}{|l|}{ Mid-ocean ridge } \\
\hline Aden Ridge & $45.6-52.7^{\circ} \mathrm{E}$ & $1,2 \dagger$ & 541.8 & $\begin{array}{l}\text { (Gamo et al. } \\
\text { 2001) }\end{array}$ \\
\hline Carlsberg Ridge & $5.5-10^{\circ} \mathrm{N}$ & 3 & 751.7 & $\begin{array}{l}\text { (Murton et al., } \\
\text { 2006) }\end{array}$ \\
\hline Chile Rise & $83-97^{\circ} \mathrm{W}$ & 3 & 818.3 & $*$ \\
\hline $\begin{array}{l}\text { Central Indian } \\
\text { Ridge }\end{array}$ & $21-25.5^{\circ} \mathrm{S}$ & $1,2,3 \dagger$ & 513.0 & $\begin{array}{l}* \text {, (Zhu et al., } \\
2008)\end{array}$ \\
\hline $\begin{array}{l}\text { Galapagos } \\
\text { Spreading Center }\end{array}$ & $101.5-102^{\circ} \mathrm{W}$ & 1 & 106.0 & $*$ \\
\hline $\begin{array}{l}\text { Galapagos } \\
\text { Spreading Center }\end{array}$ & $86-86.25^{\circ} \mathrm{W}$ & 1 & 97.9 & $*$ \\
\hline $\begin{array}{l}\text { Gulf of } \\
\text { California }\end{array}$ & $23-29^{\circ} \mathrm{N}$ & 3 & 205.7 & $*$ \\
\hline Knipovich Ridge & $74.5-78^{\circ} \mathrm{N}$ & $1,3 \dagger$ & 401.7 & $\begin{array}{l}* \text {, (Connelly et } \\
\text { al., 2007) }\end{array}$ \\
\hline $\begin{array}{l}\text { Mid-Cayman } \\
\text { Rise }\end{array}$ & entire length & 2 & 119.0 & $\begin{array}{l}\text { (German et } \\
\text { al., 2010) }\end{array}$ \\
\hline Mohns Ridge & not determined & $1,2,3$ & 78.3 & $\begin{array}{l}\text { (Pedersen } \text { et } \\
\text { al., 2010b) }\end{array}$ \\
\hline N MAR & $45.3-45.75^{\circ} \mathrm{N}$ & 1 & 43.7 & $\begin{array}{l}\text { (Searle et al., } \\
\text { 2008) }\end{array}$ \\
\hline N MAR & $38-40.1^{\circ} \mathrm{N}$ & 3 & 212.8 & $*$ \\
\hline N MAR & $21-26^{\circ} \mathrm{N}$ & $2,3 \dagger$ & 541.7 & $*$ \\
\hline $\begin{array}{l}\text { Pacific-Antarctic } \\
\text { Ridge }\end{array}$ & $\begin{array}{l}37.5-38.66^{\circ} \mathrm{S} \\
\text { and } 39.5-41.33^{\circ} \\
\mathrm{S}\end{array}$ & 3 & 338.0 & $\begin{array}{l}\text { (Stoffers et } \\
\text { al., 2002) }\end{array}$ \\
\hline S EPR & $0-3.8^{\circ} \mathrm{S}$ & $1,2 \dagger$ & 449.7 & $\begin{array}{l}\text { (Chen } \text { et al., } \\
\text { 2006), (Tao et } \\
\text { al., 2008) }\end{array}$ \\
\hline S EPR & $21.33-22.66^{\circ} \mathrm{S}$ & 2 & 164.9 & $*$ \\
\hline S MAR & $\begin{array}{l}2-2.5 \text { and } 11-14^{\circ} \\
S\end{array}$ & 2,3 & 322.1 & $\begin{array}{l}\text { *, (Tao et al., } \\
2011 \mathrm{~b})\end{array}$ \\
\hline
\end{tabular}

Back-arc

spreading center

\begin{tabular}{lllll} 
Bransfield Strait & $54.5-61^{\circ} \mathrm{W}$ & 2 & 435.0 & $*$ \\
\hline East Scotia Ridge & $55.8-56.5^{\circ} \mathrm{S}$ & 1 & 83.7 & $*$ \\
\hline
\end{tabular}




\begin{tabular}{|c|c|c|c|c|}
\hline East Scotia Ridge & $59.8-60.75^{\circ} \mathrm{S}$ & 1 & 124.4 & $*$ \\
\hline Lau Basin & $\begin{array}{l}\text { Lau NWLSC and } \\
\text { RR }\end{array}$ & $2,3 \dagger$ & 264.0 & $\begin{array}{l}\text { (Lupton et al., } \\
\text { 2012) }\end{array}$ \\
\hline Lau Basin & Lau CLSC & 1 & 144.8 & $\begin{array}{l}\text { (Arculus, } \\
\text { 2009) }\end{array}$ \\
\hline Mariana Trough & $12.7-13.2^{\circ} \mathrm{N}$ & 1 & 75.4 & $\begin{array}{l}\text { (Baker et al., } \\
\text { 2005) }\end{array}$ \\
\hline $\begin{array}{l}\text { New Hebrides } \\
\text { back-arc }\end{array}$ & Coriolis Troughs & 2,3 & $* *$ & $\begin{array}{l}\text { (Arculus and } \\
\text { McConachy, } \\
\text { 2004) }\end{array}$ \\
\hline N Fiji Basin & $\begin{array}{l}\text { central spreading } \\
\text { axis }\end{array}$ & 3 & 628.1 & $*$ \\
\hline N Fiji Basin & $21.4-21.9^{\circ} \mathrm{S}$ & 2 & 98.0 & $\begin{array}{l}\text { L. } \\
\text { Danyushevsky } \\
\text {, pers. comm. }\end{array}$ \\
\hline Okinawa Trough & SPOT & 1 & 58.4 & $\begin{array}{l}\text { (Gamo et al., } \\
\text { 2010) }\end{array}$ \\
\hline $\begin{array}{l}\text { Taupo Volcanic } \\
\text { Zone and Havre } \\
\text { Trough }\end{array}$ & $34.2-36.7^{\circ} \mathrm{S}$ & 2 & 375.0 & $\begin{array}{l}\text { (Stoffers et } \\
\text { al., 1999), } \\
\text { (Merle et al., } \\
\text { 2007) }\end{array}$ \\
\hline $\begin{array}{l}\text { Tyrrhenian back- } \\
\text { arc }\end{array}$ & Marsili & 1 & $* *$ & $\begin{array}{l}\text { (Lupton et al., } \\
\text { 2011) }\end{array}$ \\
\hline
\end{tabular}

* If no reference is listed here, the survey was included in (Baker and German, 2004), with the exception of North Fiji Basin central spreading axis which was included in (Baker et al., 1995).

$\dagger$ When we could not determine exactly which steps to be assigned to types 1,2 , or 3 , we used type 2 in Supp. Data.

+ Values for $\mathrm{F}_{\mathrm{s}}$ and $\mathrm{u}_{\mathrm{s}}$ in listing for Juan de Fuca Ridge include Explorer Ridge.

$\S$ Length is contained within the length included for this region in (Baker and German, 2004).

$\|$ Values for $\mathrm{F}_{\mathrm{s}}$ and $\mathrm{u}_{\mathrm{s}}$ include Woodlark Basin 156.1-156.4 ${ }^{\circ} \mathrm{E}$ (Segment 5B).

** BASC regions that could not be matched to PB2002 model. 


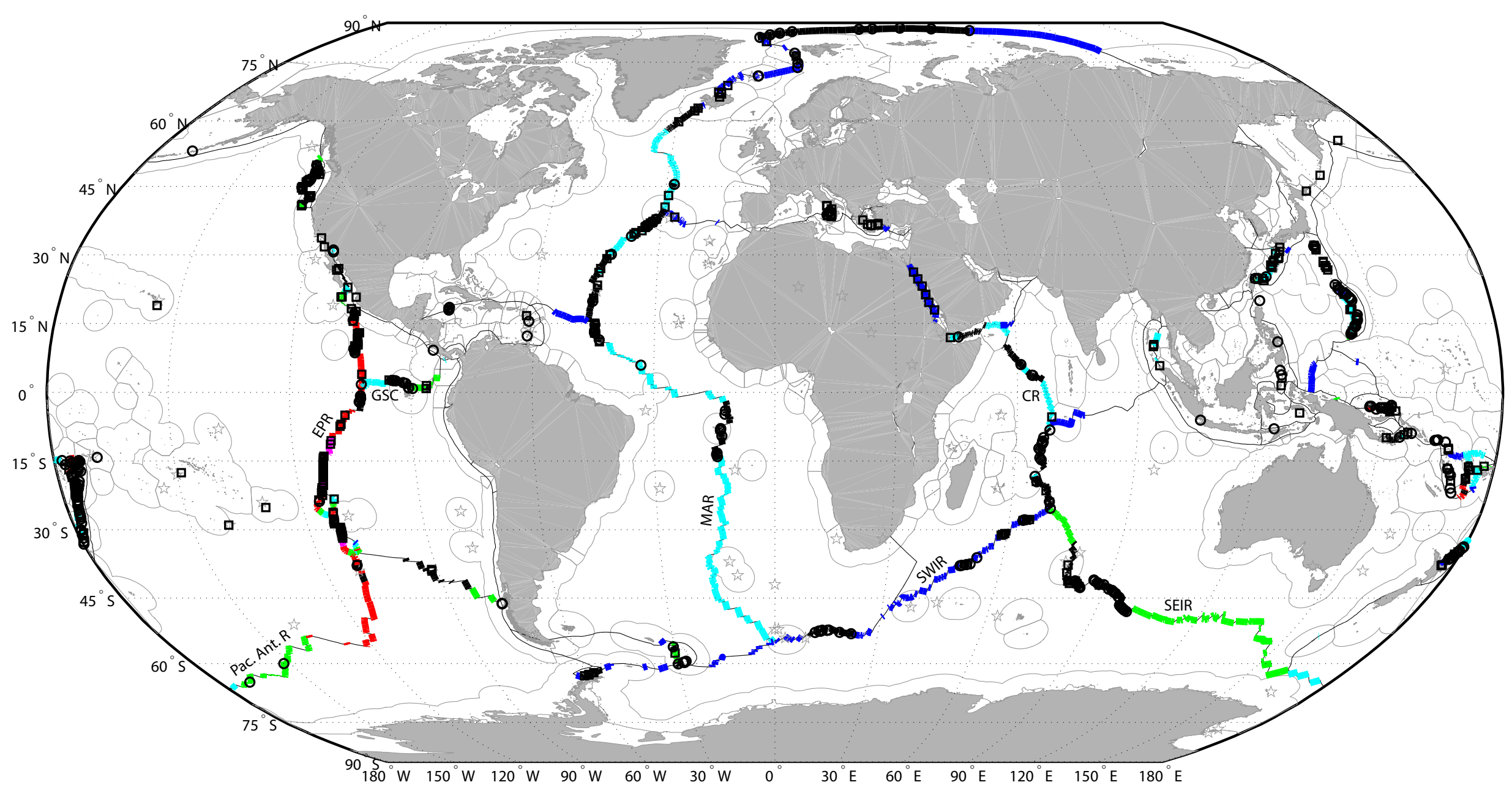

Fig. 1

Ultraslow

Slow

Intermediate

Fast

Superfast 

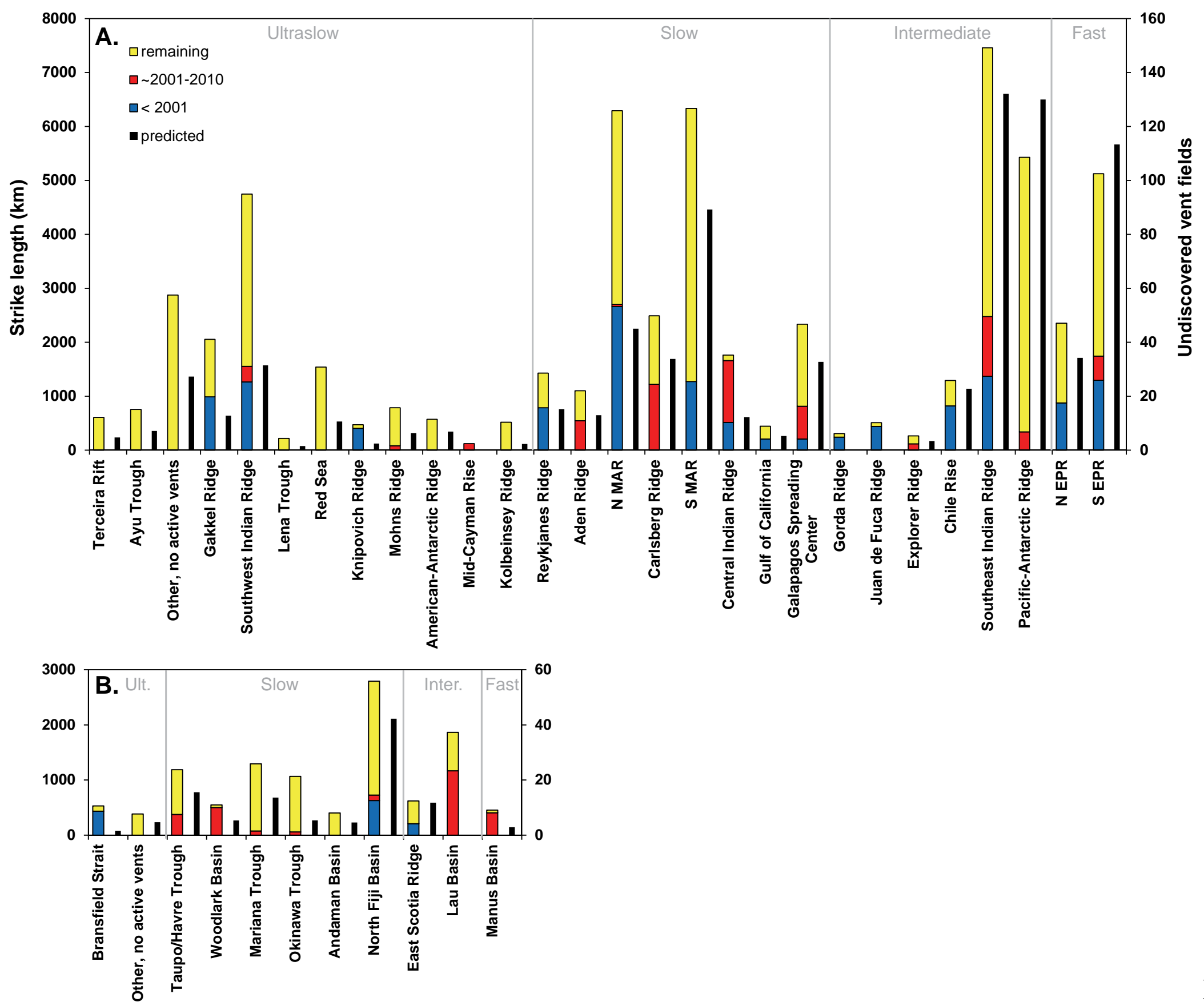

Fig. 2 


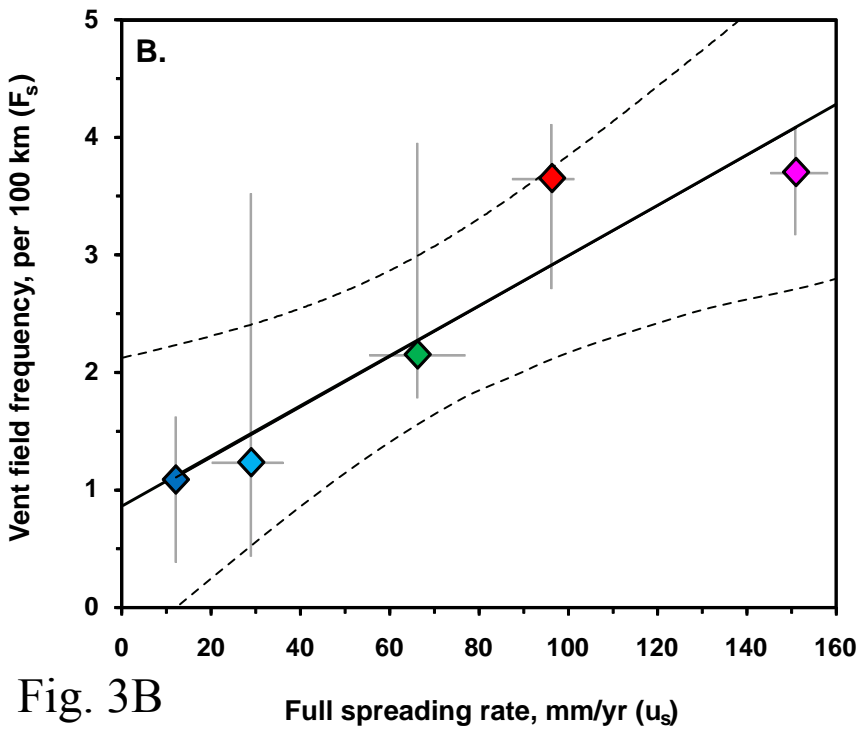




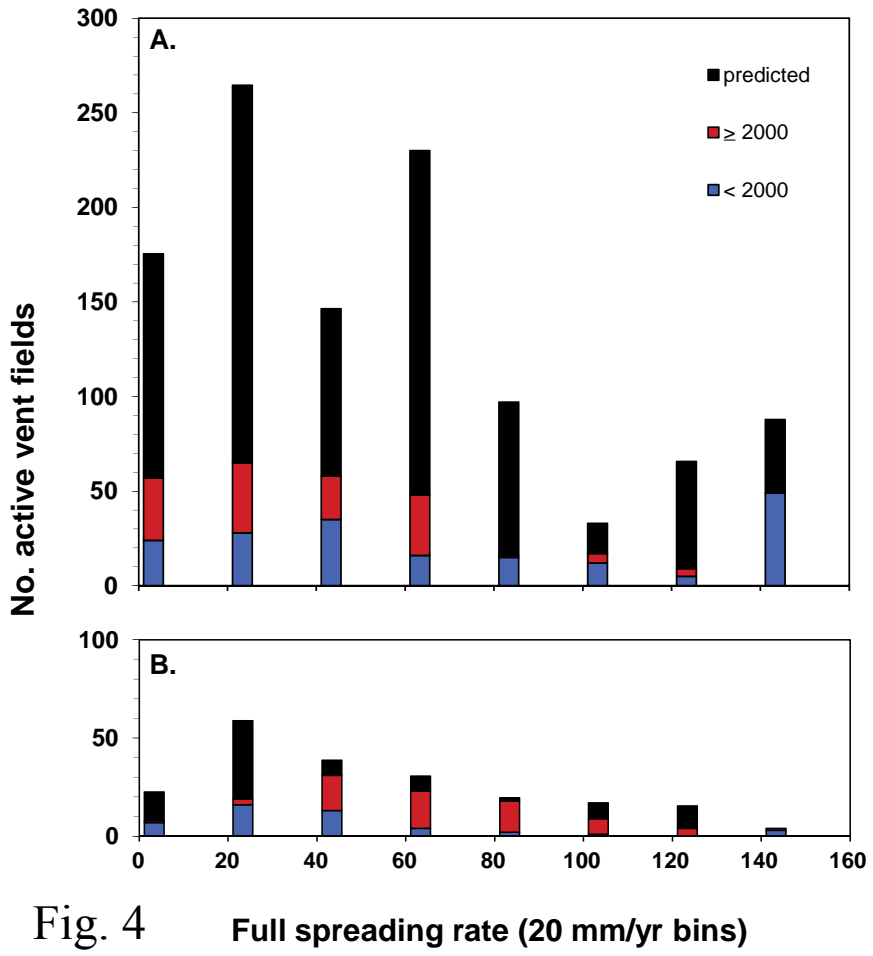

